\title{
The Analysis of Factors Affecting the Buying Interest of E-Commerce Customers
}

\author{
Harisno $^{1}$ and Deborah Herby ${ }^{2}$ \\ ${ }^{1,2}$ Information Systems Management Department, BINUS Graduate Program - Master of \\ Information Systems Management, Bina Nusantara University \\ Jakarta 11480, Indonesia \\ Email: ${ }^{1}$ harisno@binus.edu, ${ }^{2}$ deborah_0509@yahoo.com
}

\begin{abstract}
The goals of this research are to analyze factors affecting buying interest of e-commerce customers residing in the areas of Jakarta, Bogor, Depok, Tangerang, and Bekasi in Indonesia. A questionnaire is developed as the data acquisition instrument and is pretested by 30 respondents. The pretest is intended to evaluate the validity and reliability of the instrument. For the research, the data are collected from a random sample of 200 respondents. The research variables are ease of use, enjoyment, shopping experience, trust, promotion/advertising, and price. A structural equation model is established to assess the relations between the interested variables. As the results, the analysis shows that the factors of ease of use, promotion/advertising, and price significantly influence the buying interest. Meanwhile, the enjoyment, shopping experience, and trust do not affect the buying interest.
\end{abstract}

Index Terms-Interest of Customer, E-Commerce, Shopping Experience, Buying Interest

\section{INTRODUCTION}

A LONG with advances in technology, the Internet is not just media used for communication, but also for buying and selling goods. In Indonesia, the population of Internet users continues to grow each year. Based on the data from the website of the Indonesia Internet Service Provider Association 'Asosiasi Penyelenggara Jasa Internet Indonesia' (APJII) [1], from 2005 to 2014, the number of Internet users continues to grow and it reached 88.1 million in 2014 from a total of 252.4 million Indonesia population.

According to the statistics from the website of the Ministry of Communication and Information Techology 'Kementerian Komunikasi dan Informatika' (Kemkominfo) [2] in 2014, the percentage of Internet users involving in selling / buying goods / services (e-commerce) was $20.70 \%$ of the Indonesia Internet users. It means that the use of Internet in e-commerce in Indonesia is quite high and may continue to rise

Received: Mar. 14, 2017; received in revised form: Nov. 4, 2017; accepted: Oct. 30, 2017; available online: Apr. 25, 2018. each year. The use of the Internet should have great benefit for business, but it also increases the business competitiveness.

According to Ref. [3], e-commerce is the buying and selling of goods / services by using the Internet. In general, e-commerce is a place for people to shop a variety of items online. After the customer order goods and pay for it, the items will be sent to the customer directly.

By 2015, Indonesia already has many e-commerce websites according to Kemkominfo [4]. The data show that there are five most popular e-commerce websites, namely, olx.co.id, tokopedia.com, lazada.com, kaskus. co.id, and bukalapak.com.

In e-commerce, there are many kinds of segments or categories of goods and services as seen on the statistical data on the Kemkominfo website [5]. By 2015, the data shows that 10 segments are widely popular in e-commerce. Those segments are: fashion and its accessories; mobile phones, gadgets, and their accessories; electronic; sport tools; textiles and apparel; leather, bags, and shoes; household goods; health equipment; handicraft items; and power tool.

From the data, it can be seen which e-commerce and the market segment that are most frequently visited / purchased by customers. However, there is no data regarding the buying interest in e-commerce. Therefore, it is necessary to study what factors that affect the buying interest in e-commerce are.

\section{LiterATURE REVIEW}

\section{A. Previous Research}

Studies have shown that e-commerce customers have various factors affecting their buying interest. Reference [6] found that the perceived ease of use, perceived usefulness, and trust significantly influenced enjoyment. This relationship is supported by the emperical data at the coefficient of determination $\left(R^{2}\right)$ of 0.316 . 
Cite this article as: Harisno and D. Herby, "The Analysis of Factors Affecting the Buying Interest of E-Commerce Customers", CommIT (Communication \& Information Technology) Journal 12(1), 13-18, 2018.

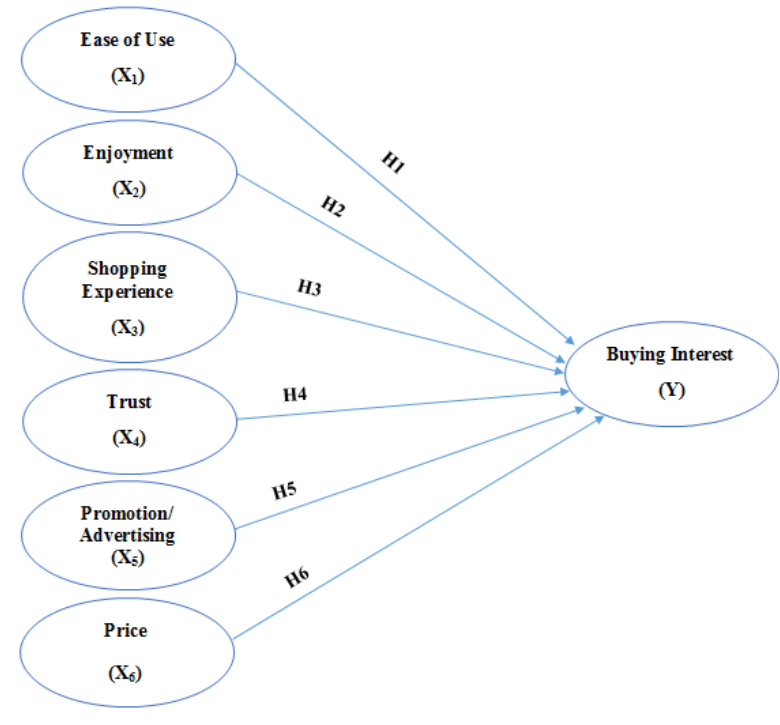

Fig. 1. Research model developed from other research.

Similarly, those independent variables also affect the repurchase intention.

According to Ref. [7], the perceived risk had a negative impact on the intention to shop online. They also found that perceived usefulness to be the strongest predictors of the intention, and followed by self-efficacy. Perceived ease of use was found as a less significant predictor. Perceived enjoyment and subjective norms partially supported the shopping intention.

According to Ref. [8], appeal and salespeople competence affected the customer buying interest. According to Ref. [9], buying interest was influenced by location, diversity of product, price, and quantity. The influence was particularly significant in the traditional market so called Bersehati. According to Ref. [10], buying interest was positively related to ease of use, pleasure, shopping experience, and customer confidence. Based on previous research on the interest of online shopping, the current research model is shown in Fig. 1.

\section{B. Structural Equation Modeling}

Structural Equation Modeling (SEM) is a statistical modeling technique that is highly crosssectional, linear and general, including factor analysis, path analysis, and regression. SEM-AMOS is an excellence program as it has the ability to create or construct a model having many latent and observable variables [11]. According to Ref. [12], SEM is a multivariate statistical technique combining factor analysis and regression analysis.

\section{RESEARCH METHOD}

\section{A. Hypothesis}

The hypotheses in this study are:

H1: Ease of use has a positive influence on buying interest.

$\mathrm{H} 2$ : Enjoyment has a positive influence on buying interest.

H3: Shopping experience has a positive influence on buying interest.

H4: Trust has a positive influence on buying interest.

H5: Promotion/advertising has a positive influence on buying interest.

H6: Price has a positive influence on buying interest.

\section{B. Data Processing}

Using the method of analysis of SEM, a merger between the two statistical concepts, namely the concept of factor analysis are represtend in the measurement model and the concept of regression through the structural model. The model explains the relationship between the variables with their indicators and structural models to explain the relationship between variables [13]. Moreover, the testing of the validity and reliability of data uses SPSS. Meanwhile, the results of the respondents are processed using SEM-AMOS.

\section{Sampling}

The sampling process is carried out in the following steps. 1) The population in this study are the users of e-commerce in Jakarta, Bogor, Depok, Tangerang, and Bekasi. 2) The sample is randomly selected from the population. 3) According to Ref. [14], the maximum likelihood estimation technique requires a sample size in the range of 100-200. Reference [12] estimated that the required sample size was in between of 150 and 400 data.

According to Ref. [12], a sample size of 200 is also acceptable on the conditions of limited resources, money, time, and population characteristics. The sample size of the current study is 200. In addition, 30 respondents are selected for the questionnaire pretest [15].

The scale of measurement used in the questionnaire is Likert scale $1-5$, where $1=$ strongly disagree, $2=$ disagree, $3=$ neutral or fair, $4=$ agree, and $5=$ strongly agree.

\section{Data Analysis}

To collect the data, the survey questionnaire is created using Google Forms. The questionnaire is divided 
Cite this article as: Harisno and D. Herby, "The Analysis of Factors Affecting the Buying Interest of E-Commerce Customers", CommIT (Communication \& Information Technology) Journal 12(1), 13-18, 2018.

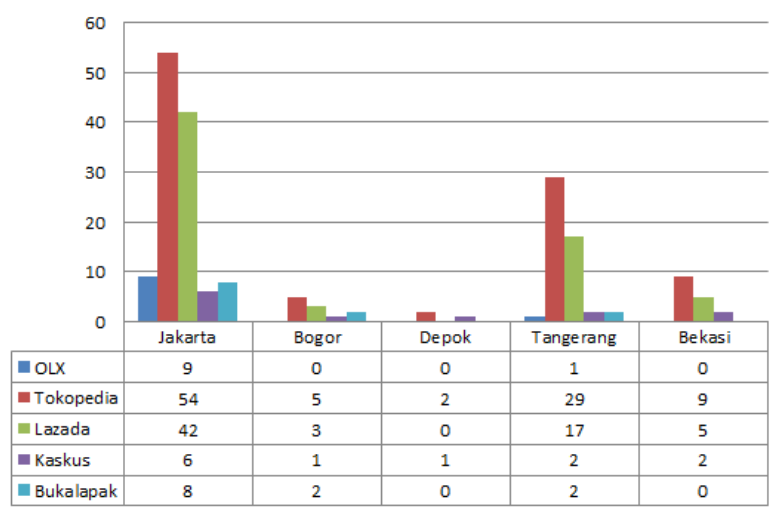

Fig. 2. The number of customers accessing the e-commerce sites from the regions: Jakarta, Bogor, Depok, Tangerang, and Bekasi.

into two parts, part A and part B. Section A contains respondent profiles such as gender, age, region, used ecommerces, the amount of spending every month, and market segment. Section B contains 23 questions.

A pilot test is conducted by using 30 respondents to determine the instrument validity and reliability. After receiving the results of validity and reliability, the questionnaire is distributed to 200 respondents. The results of data from respondents are analyzed by using SEM-AMOS.

\section{Results AND Discussion}

The questionnaire is distributed to random ecommerce customers in the areas of Jakarta, Bogor, Depok, Tangerang, and Bekasi. It also distributed online via an Indonesia community in kaskus.co.id. A total of 210 respondents returns the questionnaire but ten respondents do not fill it completely. The incomplete questionnaires are discharged.

\section{A. The Regions of E-Commerce Customers and Market Segmentation}

The first aspect is regarding the demand of ecommerce in Jakarta, Bogor, Depok, Tangerang, and Bekasi. As it can be seen in Fig. 2, the most widely accessed e-commerce is Tokopedia and most customers are from Jakarta. No respondent in Bogor, Depok, and Bekasi accesses OLX. This is also similar in Depok that no respondent accesses Lazada. Then, no respondent in Depok and Bekasi accesses Bukalapak.

In regard of the most attractive market segments of e-commerce, the results can be seen in Fig. 3. It can be seen for each e-commerce, there is a market segment frequently accessed by their user. In Lazada, one of the most widely accessed is the market segment of fashion and accessories. In this site, the less popular products are related to health tools, craft items, and power tools.
TABLE I

THE VALidity TEST OF THE INSTRUMENT.

\begin{tabular}{lccc}
\hline Variable & Item & Pearson Cor. & Result \\
\hline Ease of Use $\left(X_{1}\right)$ & $X_{1.1}$ & 0.844 & Valid \\
& $X_{1.2}$ & 0.724 & Valid \\
& $X_{1.3}$ & 0.829 & Valid \\
Enjoyment $\left(X_{2}\right)$ & $X_{1.4}$ & 0.825 & Valid \\
& $X_{2.1}$ & 0.610 & Valid \\
Shopping Exp. $\left(X_{3}\right)$ & $X_{2.2}$ & 0.802 & Valid \\
& $X_{2.3}$ & 0.727 & Valid \\
& $X_{3.1}$ & 0.879 & Valid \\
Trust $\left(X_{4}\right)$ & $X_{3.2}$ & 0.884 & Valid \\
& $X_{3.3}$ & 0.710 & Valid \\
Promotion/Ad. $\left(X_{5}\right)$ & $X_{4.1}$ & 0.778 & Valid \\
& $X_{4.2}$ & 0.774 & Valid \\
Price $\left(X_{6}\right)$ & $X_{4.3}$ & 0.763 & Valid \\
& $X_{5.1}$ & 0.733 & Valid \\
& $X_{5.2}$ & 0.879 & Valid \\
Buying Interest $(Y)$ & $X_{5.3}$ & 0.860 & Valid \\
& $X_{6.1}$ & 0.706 & Valid \\
& $X_{6.2}$ & 0.897 & Valid \\
& $X_{6.3}$ & 0.908 & Valid \\
& $Y_{.1}$ & 0.633 & Valid \\
& $Y_{.2}$ & 0.749 & Valid \\
& $Y_{.3}$ & 0.831 & Valid \\
& $Y_{.4}$ & 0.429 & Valid \\
\hline & & &
\end{tabular}

TABLE II

THE RELIABILITy TeSt OF THE InStRUMENT.

\begin{tabular}{lcl}
\hline Variable & Cronbach's $\alpha$ & Results \\
\hline Ease of Use $\left(X_{1}\right)$ & 0.816 & Reliable \\
Enjoyment $\left(X_{2}\right)$ & 0.514 & Reliable \\
Shopping Exp. $\left(X_{3}\right)$ & 0.748 & Reliable \\
Trust $\left(X_{4}\right)$ & 0.643 & Reliable \\
Promotion/Advertising $\left(X_{5}\right)$ & 0.761 & Reliable \\
Price $\left(X_{6}\right)$ & 0.789 & Reliable \\
Buying Interest $(Y)$ & 0.604 & Reliable \\
\hline
\end{tabular}

\section{B. Validity and Reliability Pilot Test}

During the deployment of the questionnaire, a pilot program is done to test the instrument. The program involves 30 respondents. The test intends to evaluate the instrument validity and reliability. The results are presented in Table I, which are acceptable at the confidence level of $95 \%$ and significance level of $5 \%$. The $r$-table value is 0.3610 . According to Ref. [16], the instrument is valid when its Pearson correlation coefficient for each measured item is larger than the table value.

The results of the reliability test of the instrument is presented in Table II. According to Ref. [17], the value of $\alpha$ between $0.50-0.70$ means moderate reliability, suggesting that the entire test items are reliable and consistent internally.

\section{Data Analysis and Discussion}

After successfully getting the respondent data, the next step is to process the data and analysis by using SEM. The analysis is performed by using AMOS soft- 
Cite this article as: Harisno and D. Herby, "The Analysis of Factors Affecting the Buying Interest of E-Commerce Customers", CommIT (Communication \& Information Technology) Journal 12(1), 13-18, 2018.

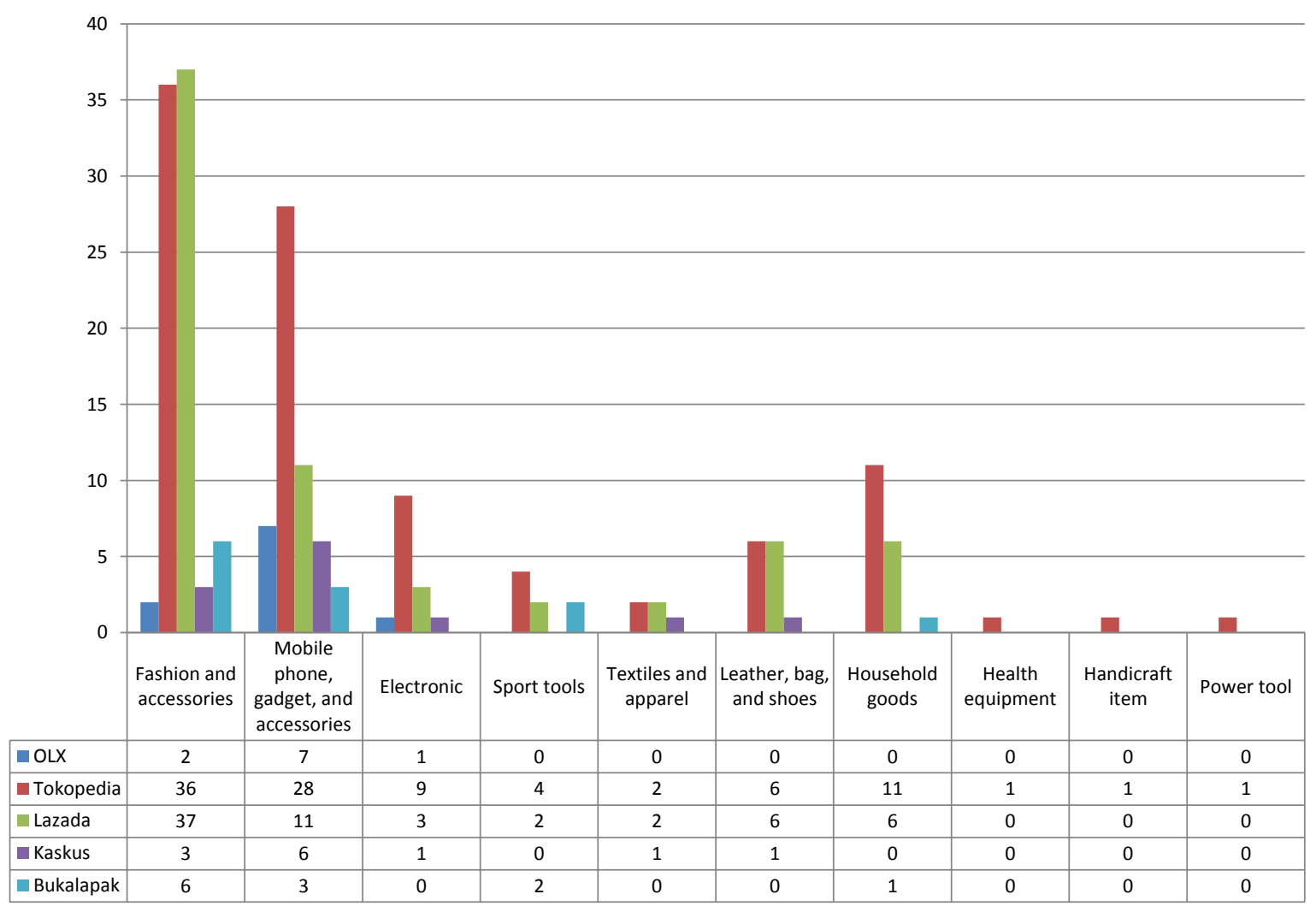

Fig. 3. The most popular types of products on OLX, Tokopedia, Lazada, Kaskus, and Bukalapak according to respondents in Jakarta, Bogor, Depok, Tangerang, and Bekasi.

TABLE III

The Degree of Freedom of THE Model.

\begin{tabular}{lc}
\hline Model Degree of Freedom: & \\
\hline Number of distinct sample moments & $: 276$ \\
Number of distinct parameters to be estimated & $: 66$ \\
Degrees of freedom $(276-66)$ & $: 210$ \\
\hline
\end{tabular}

ware version 22. Firstly, model of SEM with AMOS is created as depicted Fig. 4.

From AMOS software, the researchers obtain the problem degree of freedom of 210 , see Table III. It suggests the problem is over identifiable, and the estimation and model assessment is feasible, as suggested by Ref. [12].

Moreover, the fitness of the model to the data is as the following. The researchers use the indices discussed by Refs. [12, 18]. The first fitness criterion is the Absolute Fit Indices or GFI. For a good fitness, the index value should within the interval of 0.80 0.90 [18]. As depicted in Table IV, the current model has GFI $=0.836$, suggesting a good fitness. In addition, RMSEA is also another measure of fitness. The RMSEA index of this model is 0.079 , see Table V. It
TABLE IV

The Measure of Model Fitness: Absolute Fit Indices (GFI).

\begin{tabular}{lrrrr}
\hline Model & RMR & GFI & AGFI & PGFI \\
\hline Default model & 0.068 & 0.836 & 0.785 & 0.636 \\
Saturated model & 0.000 & 1.000 & & \\
Independence model & 0.206 & 0.322 & 0.260 & 0.295 \\
\hline
\end{tabular}

TABLE V

The Measure of Model Fitness: RMSEA.

\begin{tabular}{lrrrr}
\hline Model & RMSEA & LO 90 & HI 90 & PCLOSE \\
\hline Default model & 0.079 & 0.070 & 0.089 & 0.000 \\
Independence model & 0.194 & 0.187 & 0.202 & 0.000 \\
\hline
\end{tabular}

is lower than 0.08 , indicating a good fitness.

The model fitness can also be measured by the Incremental Fit Indices (IFI). For a good model, this index value should be in the range of $0.80-0.90$ [18]. The current model has IFI value of 0.865 .

The final fitness index is the Parsimony Fit Indices or PNFI. According to Ref. [18, 19], a good model should has PNFI $\geq 0.50$. The current model has PNFI of 0.648 as depicted in Table VII. 
Cite this article as: Harisno and D. Herby, "The Analysis of Factors Affecting the Buying Interest of E-Commerce Customers", CommIT (Communication \& Information Technology) Journal 12(1), 13-18, 2018.

TABLE VI

The Measure of Model Fitness: Incremental Fit Indices (IFI).

\begin{tabular}{lrrrrr}
\hline Model & NFI DELTA 1 & RFI rho 1 & IFI Delta 2 & TLI rho 2 & CFI \\
\hline Default & 0.781 & 0.736 & 0.865 & 0.834 & 0.862 \\
Saturated & 1.000 & & 1.000 & & 1.000 \\
Independence & 0.000 & 0.000 & 0.000 & 0.000 & 0.000 \\
\hline
\end{tabular}

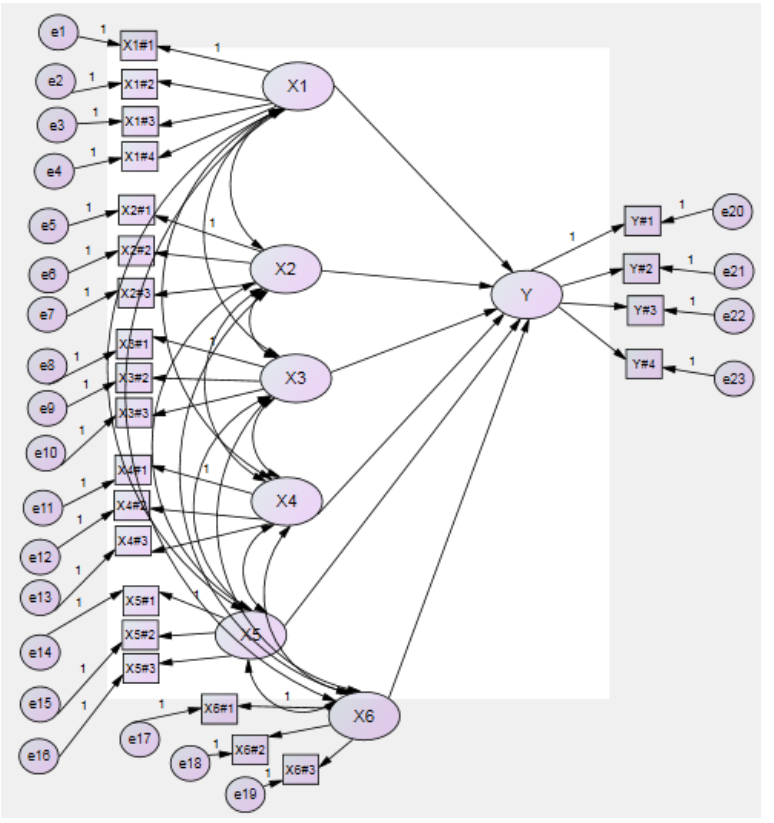

Fig. 4. The path diagram with Amos, where $X_{1}=$ Ease of Use, $X_{2}=$ Enjoyment, $X_{3}=$ Shopping Experience, $X_{4}=$ Trust, $X_{5}=$ Promotion/Advertising, $X_{6}=$ Price, and $Y=$ Buying Interest.

TABLE VII

The Measure of Model Fitness: Parsimony Fi Indices (PNFI).

\begin{tabular}{lrrr}
\hline Model & PRATIO & PNFI & PCFI \\
\hline Default model & 9.830 & 0.648 & 0.715 \\
Saturated model & 0.000 & 0.000 & 0.000 \\
Independence model & 1.000 & 0.000 & 0.000 \\
\hline
\end{tabular}

For the conclusion regarding the model fitness, the developed model fits the data in accordance with all fitness indices. In this stage, the researchers can access the relationship between independent and dependent variables. The results are summarized in Table VIII.

From the results, the findings can be summarized. The hypothesis $1\left(\mathrm{H}_{1}\right)$ that ease of use has a positive and significant effect on the buying interest, is accepted. The hypothesis $2\left(\mathrm{H}_{2}\right)$ is rejected. Enjoyment has no positive effect on the buying interest. The hypothesis $3\left(\mathrm{H}_{3}\right)$ or shopping experience has positive effect to the buying interest, is also rejected. Next, the hypothesis $4\left(\mathrm{H}_{4}\right)$ is rejected. It does not prove
TABLE VIII

ESTIMATES AND SIGNIFICANCE.

\begin{tabular}{lrr}
\hline$X \rightarrow Y$ & Estimate & $p$-value \\
\hline Ease of Use $\rightarrow$ Buying Interest & 0.261 & 0.013 \\
Enjoyment $\rightarrow$ Buying Interest & 0.072 & 0.566 \\
Shopping Exp. $\rightarrow$ Buying Interest & 0.044 & 0.557 \\
Trust $\rightarrow$ Buying Interest & -0.246 & 0.066 \\
Promotion/Ad. $\rightarrow$ Buying Interest & 0.227 & 0.031 \\
Price $\rightarrow$ Buying Interest & 0.476 & 0.006 \\
\hline
\end{tabular}

that trust has an effect on buying interest. The last two hypotheses $\left(\mathrm{H}_{5}\right.$ and $\left.\mathrm{H}_{6}\right)$ are accepted. Promotion/ advertising and price has positive effect on the buying interest.

\section{CONClusion}

This research is conducted to find the factors affecting the interest of customer e-commerce shopping. The three accepted hypotheses are $\mathrm{H}_{1}, \mathrm{H}_{5}$, and $\mathrm{H}_{6}$. The three rejected hypotheses are $\mathrm{H}_{2}, \mathrm{H}_{3}$, and $\mathrm{H}_{4}$. These are similar to the results obtained by Refs. [6-10].

The first accepted hypothesis argues that the ease of use has positive and significant impact on buying interest. This finding is supported by Refs. [6, 10].The second hypothesis that the enjoyment has a positive and significant impact on buying interest, is rejected. Similarly, the third hypothesis that the shopping experience has a positive and significant effect on buying interest, is also rejected. The fourth hypothesis is also rejected.The trusts has no positive and significant impact on buying interest.

The fifth hypothesis that the promotion / advertising has a positive and significant impact on buying interest, is accepted. The result is in accordance with the findings of Ref. [8]. In addition, the sixth hypothesis is also accepted. The price has a effect positive and significant impact on buying interest. Similar finding is obtained by Ref. [9]. The study concludes the factors affecting the buying interest of e-commerce customer. In the order of importance, there are the price, easy of use, and promotion/advertising.

\section{ACKNOWLEDGEMENT}

I would like to extend my thank to Prof. Dr. Ir. Harjanto Prabowo, M.M., as Rector Bina Nusantara 
University, who has provided the opportunity to complete a master degree in Master of Information System Management Study Program and gives the permission to submit scientific articles to international conference. All the constructive feedbacks from reviewers are highly appreciated.

\section{REFERENCES}

[1] APJII. (2014) Profil pengguna internet indonesia 2014. Asosiasi Penyelenggara Jasa Internet Indonesia. [Online]. Available: www.apjii.or.id/content/read/39/27/ PENGGUNA-INTERNET-INDONESIA-2014.

[2] Kominfo. (2016) Aktivitas utama dalam mengakses internet pada tahun 2014. Kementrian Komunikasi dan Informatika Republik Indonesia. [Online]. Available: http://statistik.kominfo.go.id/site/data? idtree $=424 \&$ iddoc $=1466 \&$ data-data $\_$page $=2$.

[3] J. L. Whitten, Metode desain dan analisis sistem. Yogyakarta: Graha Ilmu, 2008.

[4] Kominfo. (2015) A familiar sites used by the purchaser in e-commerce transactions by 2015 . Kementrian Komunikasi dan Informatika Republik Indonesia. [Online]. Available: http://statistik. kominfo.go.id/site/data?idtree $=430 \&$ iddoc $=1467$

[5] — . (2015) Classification of products purchased online in 2015. Kementrian Komunikasi dan Informatika Republik Indonesia. [Online]. Available: http://statistik.kominfo.go.id/site/data? idtree $=430 \&$ iddoc $=1457 \&$ data-data_page $=2$

[6] S. Aren, M. Guzel, E. Kabadayi, and L. Alpkan, "Factors affecting repurchase intention to shop at the same website," Procedia-Social and Behavioral Sciences, vol. 99, pp. 536-544, 2013.

[7] A. Mandilas, A. Karasavvoglou, M. Nikolaidis, and L. Tsourgiannis, "Predicting consumer's perceptions in on-line shopping," Procedia Technology, vol. 8, pp. 435-444, 2013.

[8] E. Dwityanti, "Analisis faktor-faktor yang mempengaruhi minat beli konsumen terhadap layanan internet banking mandiri studi kasus pada karyawan departemen pekerjaan umum jakarta," Ph.D. dissertation, program Pascasarjana Universitas Diponegoro, 2008.

[9] H. Fure, "Lokasi, keberagaman produk, harga, dan kualitas pelayanan pengaruhnya terhadap minat beli pada pasar tradisional bersehati calaca," Jurnal Emba: Jurnal Riset Ekonomi, Manajemen, Bisnis dan Akuntansi, vol. 1, no. 3, 2013.

[10] P. A. Nurrahmanto and E. Rahardja, "Pengaruh kemudahan penggunaan, kenikmatan berbelanja, pengalaman berbelanja dan kepercayaan konsumen terhadap minat beli konsumen di situs jual beli online bukalapak.com," Ph.D. dissertation, Fakultas Ekonomika dan Bisnis, 2015.

[11] S. Bahri and F. Zamzam, Model penelitian kuantitatif berbasis SEM-Amos. Yogyakarta: Deepublish, 2014.

[12] S. Santoso, Structural Equation Modeling (Basic concepts and applications with AMOS 22). Jakarta : PT Elex Media Komputindo, 2015.

[13] W. Widhiarso, Praktek Model Persamaan Struktural (SEM) melalui program Amos. UGM, 2009.

[14] Z. Mustafa and T. Wijaya, Panduan teknik statistik SEM \& PLS dengan SPSS Amos. Yogyakarta: Cahaya Atma Pustaka, 2012.

[15] S. Uma, Metode penelitian bisnis. Jakarta: Salemba Empat, 2006.

[16] I. Ghazali, Aplikasi analisis multivariate dengan program IBM SPSS 21 Update PLS Regresi. Semarang: Badan Penerbit Universitas Diponegoro, 2013.

[17] A. T. Basuki and N. Prawoto, Analisis regresi dalam penelitian ekonomi \& bisnis (Dilengkapi aplikasi SPSS \& EVIEWS). PT Raja Grafindo Persada Jakarta, 2016.

[18] S. H. Wijanto, Metode penelitian menggunakan Structural Equation Modeling dengan LISREL 9. Jakarta: Lembaga Penerbit Fakultas Ekonomi UI, 2015.

[19] K. J. Kim and S. S. Sundar, "Does screen size matter for smartphones? Utilitarian and hedonic effects of screen size on smartphone adoption," Cyberpsychology, Behavior, and Social Networking, vol. 17, no. 7, pp. 466-473, 2014. 